\title{
Early-Life Stress Disrupts Attachment Learning: The Role of Amygdala Corticosterone, Locus Ceruleus Corticotropin Releasing Hormone, and Olfactory Bulb Norepinephrine
}

\author{
Stephanie Moriceau, ${ }^{1,2,4}$ Kiseko Shionoya, ${ }^{4,5}$ Katherine Jakubs, ${ }^{4,6}$ and Regina M. Sullivan ${ }^{1,2,3,4}$ \\ ${ }^{1}$ Emotional Brain Institute, Nathan Kline Institute, Orangeburg, New York 10962, ${ }^{2}$ Child and Adolescent Psychiatry, Child Study Center, New York \\ University Langone Medical Center, New York, New York 10016, ${ }^{3}$ New York University Center for Neural Science, New York, New York 10003, \\ ${ }^{4}$ Department of Zoology, University of Oklahoma, Norman, Oklahoma 73019, ${ }^{5}$ Laboratory Neurosciences Sensorielles, Centre National de la \\ Recherche Scientifique, Universite Lyon, 69007 Lyon, France, and 'National Institutes of Health, Bethesda, Maryland 20892
}

Infant rats require maternal odor learning to guide pups' proximity-seeking of the mother and nursing. Maternal odor learning occurs using a simple learning circuit including robust olfactory bulb norepinephrine (NE), release from the locus ceruleus (LC), and amygdala suppression by low corticosterone (CORT). Early-life stress increases NE but also CORT, and we questioned whether early-life stress disrupted attachment learning and its neural correlates [2-deoxyglucose (2-DG) autoradiography]. Neonatal rats were normally reared or stressed-reared during the first $6 \mathrm{~d}$ of life by providing the mother with insufficient bedding for nest building and were odor- $0.5 \mathrm{~mA}$ shock conditioned at $7 \mathrm{~d}$ old. Normally reared paired pups exhibited typical odor approach learning and associated olfactory bulb enhanced 2-DG uptake. However, stressed-reared pups showed odor avoidance learning and both olfactory bulb and amygdala 2-DG uptake enhancement. Furthermore, stressed-reared pups had elevated CORT levels, and systemic CORT antagonist injection reestablished the age-appropriate odor-preference learning, enhanced olfactory bulb, and attenuated amygdala 2-DG. We also assessed the neural mechanism for stressed-reared pups' abnormal behavior in a more controlled environment by injecting normally reared pups with CORT. This was sufficient to produce odor aversion, as well as dual amygdala and olfactory bulb enhanced 2-DG uptake. Moreover, we assessed a unique cascade of neural events for the aberrant effects of stress rearing: the amygdala-LC-olfactory bulb pathway. Intra-amygdala CORT or intra-LC corticotropin releasing hormone (CRH) infusion supported aversion learning with intra-LC CRH infusion associated with increased olfactory bulb NE (microdialysis). These results suggest that early-life stress disturbs attachment behavior via a unique cascade of events (amygdala-LC- olfactory bulb).

\section{Introduction}

Early-life stress appears to disrupt the programming of the hypothalamus-pituitary-adrenal axis, the limbic system (hippocampus, amygdala, prefrontal cortex, etc.), and the locus ceruleus (LC), all of which are considered critical mediators of early-life trauma on later life compromised mental health in humans and animal models (Caldji et al., 1998; Glaser, 2000; Dent et al., 2001; Sanchez et al., 2001; Grossman et al., 2003; Teicher et al., 2003; De Bellis, 2005; Plotsky et al., 2005; Gunnar and Quevedo, 2007; Champagne et al., 2008; McEwen, 2008; Cirulli et al., 2009; Gunnar et al., 2009; Lupien et al., 2009). Furthermore, early-life prolonged stress produces an exaggerated corticosterone (CORT) response, increased corticotropin releasing hormone $(\mathrm{CRH})$ expression, and heightened norepinephrine (NE) levels (Smith et al., 1997; Hatalski et al., 1998; Koob,

Received Aug. 20, 2009; revised 0ct. 9, 2009; accepted 0ct. 19, 2009.

This work was funded by National Institutes of Health Grants DC003906 and DC009910, National Science Foundation Grant I0B0850527, the Leon Levy Foundation, and the Hope for Depression Foundation (R.M.S.).

Correspondence should be addressed to Stephanie Moriceau, The Nathan Kline Institute, Emotional Brain Institute, 140 Old Orangeburg Road, Orangeburg, NY 10962. E-mail: SMoriceau@nki.rfmh.org.

DOI:10.1523/JNEUROSCI.4106-09.2009

Copyright $\odot 2009$ Society for Neuroscience 0270-6474/09/2915745-11\$15.00/0
1999; Koob and Heinrichs, 1999; Vazquez et al., 2006; Korosi and Baram, 2008).

These neural targets of early stress may have particular importance because they overlap with the infant's unique attachment learning neural circuit, which is used to support attachment to the mother via learning the maternal odor (Brunjes and Alberts, 1979; Galef and Kaner, 1980; Campbell, 1984; Sullivan et al., 1986, 1990, 2000a; Moriceau and Sullivan, 2004b; Roth and Sullivan, 2005; Moriceau et al., 2006). This circuit also enables myriad stimuli (milk, stroking, $0.5 \mathrm{~mA}$ shock) to support this odor learning required for pup survival and is characterized by robust odor approach learning and attenuated aversion learning even when the reinforcer is painful, such as $0.5 \mathrm{~mA}$ shock, tail pinch (Haroutunian and Campbell, 1979; Sullivan et al., 1986; Camp and Rudy, 1988; Sullivan et al., 2000a), or abusive mother (Roth and Sullivan, 2005). The enhanced learned odor approach responses is supported by a unique infant hyperfunctioning LC that releases copious amounts of NE into the olfactory bulb to produce the learning-induced plasticity of the olfactory bulb (Shipley et al., 1985; McLean and Shipley, 1991; Sullivan and Wilson, 1991, 1995; Wilson and Sullivan, 1991; Rangel and Leon, 1995; Langdon et al., 1997; Moriceau and Sullivan, 2004b). It is 
important to mention that moderate levels of olfactory bulb NE support preference learning, whereas higher NE levels support aversion learning in rat pups (Sullivan et al., 1989, 1991; Yuan et al., 2000; Harley et al., 2006; Christie-Fougere et al., 2009). The attenuated odor avoidance learning is supported by suppression of amygdala attributable to pups' naturally low CORT, and CORT is critical for early-life amygdala plasticity (Sullivan et al., 2000a; Moriceau and Sullivan, 2006; Moriceau et al., 2006). Indeed, in older animals, CORT increase produces a cascade of events beginning with CORT activation of the amygdala increasing the expression of $\mathrm{CRH}$ mRNA into the central amygdala (Makino et al., 1994; Hatalski et al., 1998; Hsu et al., 1998; Van Bockstaele et al., 1998; Korosi and Baram, 2008) and then CRH release exciting the LC to increase the release of NE (Butler et al., 1990; Makino et al., 1994; Curtis et al., 1997; Hatalski et al., 1998; Hsu et al., 1998; Lehnert et al., 1998; Van Bockstaele et al., 1998, 2001; Page and Abercrombie, 1999; Bouret et al., 2003; Dunn et al., 2004; Jedema and Grace, 2004; Korosi and Baram, 2008).

Thus, there is overlap in the attachment learning circuit and the targets of early-life prolonged stress, and here we test whether this is important for the unique effects of stress in infancy. Specifically, we describe a functionally compromised attachment neural circuit produced by early-life stress that may contribute to the enduring effects of early-life stress via disrupted social behavior of pups to the mother.

\section{Materials and Methods}

\section{Subjects}

Subjects were both male and female Long-Evans rat pups born and bred in our colony (originally from Harlan Lab Animals). Mothers and pups were housed in polypropylene cages $(34 \mathrm{~cm}$ width $\times 29 \mathrm{~cm}$ length $\times 17$ $\mathrm{cm}$ height) lined with pine shavings and were kept in a temperaturecontrolled $\left(23^{\circ} \mathrm{C}\right)$ and light-controlled (7:00 A.M. to 7:00 P.M.) room. Food and water were available ad libitum. The day of parturition was considered postnatal day 0 ( $\mathrm{P} 0$ ), and litters were culled to 12 on P1. No more than one male and one female from a litter were used in each experimental condition, and no difference in behaviors or neural activity between male and female was found. All procedures were approved by the Institutional Animal Care and Use Committee and followed National Institutes of Health guidelines.

\section{Stressed rearing}

From P1 to P7, the dam and her pups were housed in a cage with limited nesting/bedding material, a modified version of the Baram procedure [1000 ml, 0.5 inch layer compared with the normal $4500 \mathrm{ml}, 3$ inch layer (Gilles et al., 1996; Brunson et al., 2005)]. This limited bedding environment decreased the dams' ability to construct a nest, which results in frequent nest building, transporting/rough handling of pups, and less licking and nursing (Table 1). No significant difference in weight between conditioning group and rearing condition was found $\left(F_{(3,46)}=\right.$ $0.236, p<0.8707$ ), which replicates previous research (Gilles et al., 1996; Avishai-Eliner et al., 2001).

Maternal and pup behaviors were observed two times a day (day and night), with each session lasting $30 \mathrm{~min}$. The maternal behaviors observed were as follows: (1) stepping/jumping on, in which the mother steps or jumps on the pup; (2) rough handling, in which the mother aggressively grooms a pup or transports a pup by a limb; (3) chase tail, in which the mother was running after its own tail; (4) nest building, in which the mother was building a nest; (5) licking, in which the mother was licking its pups; and (6) nursing, in which the mother was nursing the pups.

\section{Systemic drug injection}

P7 pups were injected with either CORT (Corticosterone HBC complex, $3.0 \mathrm{mg} / \mathrm{kg}$, i.p., dissolved in saline; Sigma), CORT antagonist (mifepristone, RU 38486, $5.0 \mathrm{mg} / \mathrm{kg}$, i.p., dissolved in saline; Sigma), or saline
Table 1. Frequency of maternal behaviors observed during mother-infant interactions within the normally reared and stressed-reared paradigm

\begin{tabular}{lll}
\hline & \multicolumn{2}{c}{ Percentage of observation periods in which behaviors occurred } \\
\cline { 2 - 3 } & Stressed-reared paradigm & Normally reared paradigm \\
\hline Abnormal behaviors & & \\
$\quad$ Steps or jump on & $41.0 \%$ & $2.0 \%$ \\
$\quad$ Rough handling & $9.0 \%$ & $0 \%$ \\
$\quad$ Chase tail & $5.0 \%$ & $0 \%$ \\
$\quad$ Nest building & $19.0 \%$ & $6.0 \%$ \\
Normal behaviors & & \\
$\quad$ Lick & $12.0 \%$ & $33.0 \%$ \\
$\quad$ Nurse & $45.0 \%$ & $75.0 \%$ \\
Weight of pups & $15.01 \mathrm{~g}$ & $14.22 \mathrm{~g}$ \\
\hline
\end{tabular}

(Takahashi, 1994; Moriceau and Sullivan, 2004a) $24 \mathrm{~h}$ and $30 \mathrm{~min}$ before conditioning.

\section{Radioimmunoassay}

The levels of circulating CORT were determined from heart blood of P7 pups after normal rearing and stressed-rearing. Pups were anesthetized with pentobarbital and blood taken from the heart's ventricle via a thoracotomy through the diaphragm using a 23 gauge needle. All blood was collected between 12 and $2 \mathrm{pm}$ immediately after conditioning. Blood samples were centrifuged at 14,000 rpm for $6 \mathrm{~min}$. Plasma was stored at $-70^{\circ} \mathrm{C}$ until radioimmunoassay was performed. Duplicate plasma samples were analyzed for CORT using the Rat Corticosterone Coat-aCountkit (Radioassay Systems Labs). The sensitivity of the assay was 5 $\mathrm{ng} / \mathrm{ml}$. The intraassay coefficient of variation was $1-9 \%$.

\section{Surgery}

On P5, pups were anesthetized by inhalation (with isoflurane) and placed in an adult stereotaxic apparatus modified for use with infants. Stainless steel cannulas (30 gauge tubing) were implanted bilaterally in the LC or the amygdaloid complex through holes drilled in the overlying skull. Stereotaxic coordinates derived from the atlas of Paxinos were used as reference and adapted through pilot work (Paxinos et al., 1991; Sullivan et al., 2000b) for implanting cannulas into the LC (caudal, $-1.40 \mathrm{~mm}$; lateral, $\pm 0.60 \mathrm{~mm}$ from lambda) or into the amygdaloid complex (cau$\mathrm{dal},-0.80 \mathrm{~mm}$; lateral, $\pm 3.00 \mathrm{~mm}$ from bregma). The cannulas were lowered $5.5 \mathrm{~mm}$ (LC) or $5.0 \mathrm{~mm}$ (amygdala) from the surface of the skull. The cannulas were fixed to the skull with dental cement. To ensure patency of the cannulas, guide wires were placed in the lumen of the tubing until conditioning. After recovery from surgery (generally within $30 \mathrm{~min}$ ), pups were returned to the dam and littermates for a $2 \mathrm{~d}$ recovery period until conditioning. The survival rate of the surgery was $91 \%$, including recovery from anesthesia and cannibalism from the mother.

\section{Pharmacological treatment}

On the day of the conditioning, bilateral cannulas were attached with polyethylene PE10 tubing to a Harvard syringe pump driving two Hamilton microliter syringes. The cannulas were filled (10 s for amygdala cannulas and $12 \mathrm{~s}$ for LC cannulas at rate of $0.5 \mu \mathrm{l} / \mathrm{min}$ ) with either drug (described below) or control. During the first 20 min conditioning period, for both pups with amygdaloid cannulas or LC cannulas, drug or control was infused at $0.1 \mu \mathrm{l} / \mathrm{min}$, for a total infusion volume of $2.0 \mu \mathrm{l}$ as described previously (Sullivan et al., 1992, 2000b; Moriceau and Sullivan, 2004b). After conditioning, pups were disconnected from the syringe pump and returned to the nest until testing the following day.

Amygdala infusions. Pups with bilateral cannulas into the amygdala received either CORT (50 or $100 \mathrm{ng}$; Sigma) or cholesterol (Sigma).

LC infusions. Pups with bilateral cannulas implanted into the LC received either CRH (50, 100, or 200 ng; Sigma) or saline.

\section{Odor-0.5 mA shock conditioning}

On P7, pups were randomly assigned to one of the three following conditioning groups: (1) paired odor-shock, (2) unpaired odor-shock, or (3) odor only. Pups were placed in individual $600 \mathrm{ml}$ clear plastic beakers and given a $10 \mathrm{~min}$ adaptation period to recover from experimental 
handling. During a $45 \mathrm{~min}$ conditioning session, pups received 11 presentations of a $30 \mathrm{~s}$ peppermint odor [conditioned stimulus (CS)] and a $1 \mathrm{~s}, 0.5$ $\mathrm{mA}$ footshock (unconditioned stimulus; Lafayette scrambled shock generator), with an intertrial interval of $4 \mathrm{~min}$. Peppermint odor was delivered by a flow dilution olfactometer $(2 \mathrm{~L} / \mathrm{min}$ flow rate) at concentration of 1:10 peppermint vapor. Paired odor-shock pups received a shock overlapping with the last second of the $30 \mathrm{~s}$ odor presentation. Unpaired odor-shock pups received the shock and odor presentation pseudorandomly. Odor and shock were never coincident in this group. Odor-only pups received only the peppermint odor presentation.

During conditioning, the number of limbs moving was recorded $(0$ indicated no movement of the extremities; 5 indicated movement of all five extremities, including head) $20 \mathrm{~s}$ before presentation as well as the first $20 \mathrm{~s}$ of the odor presentation and the shock delivery (Hall, 1979).

\section{Behavioral testing: $Y$-maze}

The day after conditioning, pups were given a Y-maze test consisting of a start box $(8.5 \times 10 \times 8 \mathrm{~cm})$ and two arms $(8.5 \times 24 \times 8 \mathrm{~cm})$ separated via two sliding doors. This test required pups to choose between two arms of a Plexiglas Y-maze, one containing the peppermint odor CS $(25 \mu \mathrm{l}$ of peppermint odor placed on a Kim Wipe) and the other containing the familiar odor of pine shavings $(20 \mathrm{ml}$ of clean shaving in a Petri dish, same bedding used in home cage). For $5 \mathrm{~s}$ before the door to each arm was opened, a pup was placed in the start box. Each pup was given $60 \mathrm{~s}$ to choose an arm. A response was considered a choice when a pup's entire body was past the entrance to the alley. Pups received five trials with $30 \mathrm{~s}$ between trials, and the floor was wiped clean between each trial (Sullivan and Wilson, 1991). The testing was done blind to the conditioning groups, and no drugs were infused during testing.

\section{Behavioral testing: immobility/freezing}

It should be noted that pups do not show the entire spectrum of behaviors associated with freezing in the adult rat. For example, there is no piloerection and crouching position in P7-P8 pups, and immobile/freezing was defined as the cessation of body movement (Takahashi, 1994; Hunt and Campbell, 1999; Richardson et al., 2000; Wiedenmayer and Barr, 2001; Moriceau et al., 2004). Odors were presented to pups the day after conditioning. Pups were placed in individual $600 \mathrm{ml}$ plastic beakers and given $5 \mathrm{~min}$ adaptation period to recover from experimenter handling. They were then given five odor presentations ( $2 \mathrm{~L} / \mathrm{min}, 1: 10$ odor/ air ratio, intertrial interval of $4 \mathrm{~min}$ ). The odor was presented with an olfactometer as described above (same intensity and flow rate).

\section{Microdialysis procedure}

P5 rat pups were anesthetized by isoflurane and placed in a stereotaxic frame adapted for rat pup surgery as described previously. A cannula was placed into the right LC (used to infused CRH), and a microdialysis guide cannula ( $8 \mathrm{~mm}$ long, $500 \mu \mathrm{m}$ diameter acrylic resin; EICOM) was positioned into the right olfactory bulb; two additional holes were drilled for two skull screws (EICOM), and both were secured to the skull with dental cement. After surgery, pups were returned to the dam and littermates for a $1 \mathrm{~d}$ recovery period before experimentation.

On the day of the experiment, pups were placed in a $27-\mathrm{cm}$-diameter acrylic circular cage (EICOM) and were able to move freely and kept at $27^{\circ} \mathrm{C}$. The guide cannula was used for insertion of the microdialysis probe (A-I-8-02, $8 \mathrm{~mm}$ length, $2 \mathrm{~mm}$ membrane, $220 \mu \mathrm{m}$ diameter; EICOM). The probes were perfused with artificial CSF (in mM: $147 \mathrm{NaCl}$, $2.7 \mathrm{KCl}, 1.2 \mathrm{CaCl}_{2}$, and $0.85 \mathrm{MgCl}_{2}$ ) at a flow rate of $1.5 \mu \mathrm{l} / \mathrm{min}$. The dead volume of the collection apparatus is $4 \mu \mathrm{l}$. Dialysate was collected automatically in a refrigerated $\left(4^{\circ} \mathrm{C}\right)$ microfraction collector (EFC-82; EICOM) in which every vial contained $2 \mu \mathrm{l}$ of $12.5 \mathrm{~mm}$ perchloric acid/ $250 \mu \mathrm{M}$ EDTA. After completion of the experiment, dialysate samples were immediately stored at $-80^{\circ} \mathrm{C}$ until HPLC analysis.

NE was assessed by HPLC with electrochemical detection (HPLC-EC). HPLC-EC consisted of a $150 \times 2.1 \mathrm{~mm}$ SC-5ODS, $5 \mu \mathrm{m}$ particle column (EICOM). Mobile phase ( $0.1 \mathrm{~m}$ citric acid, $0.25 \mathrm{~mm}$ octyl sulfate sodium salt, $0.5 \mathrm{~mm}$ EDTA, $0.085 \mathrm{~mm}$ tryethylamine, and $6 \%$ acetonitrile, $\mathrm{pH}$ 2.4) was delivered at $0.23 \mathrm{ml} / \mathrm{min}$ by a EICOM EP-300 pump. Neurotransmitters were detected with a graphite carbon detector electrode maintained at $+0.75 \mathrm{~V}$ relative to an $\mathrm{Ag} / \mathrm{AgCl}$ reference
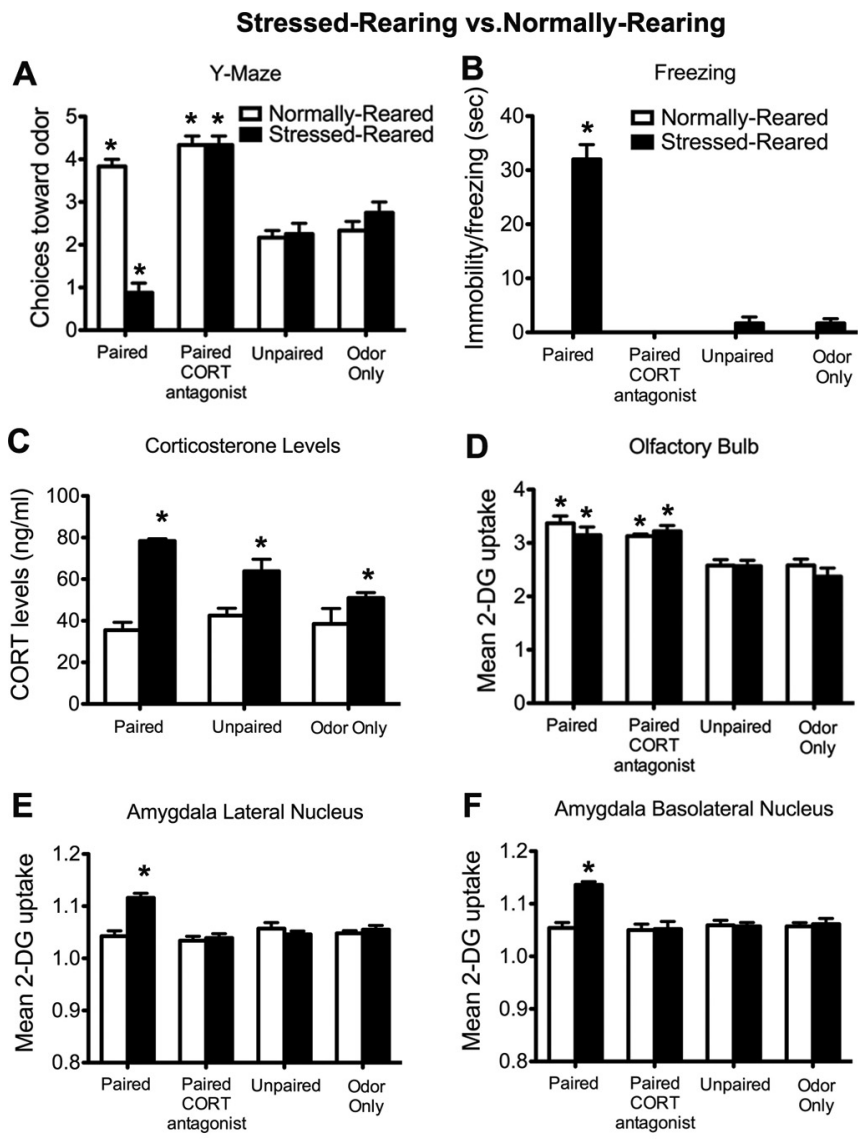

F Amygdala Basolateral Nucleus

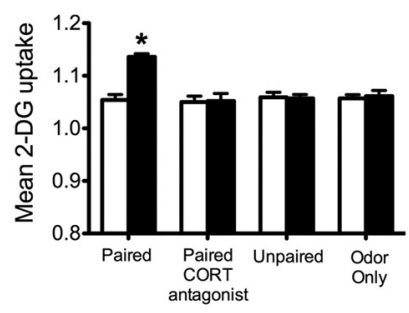

G

Amygdala Central Nucleus

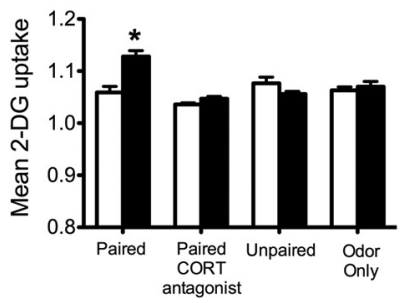

Figure 1. P7 pups stressed-reared versus normally reared and odor- $0.5 \mathrm{~mA}$ shock conditioning. $\boldsymbol{A}$, Number of choices toward the $C S$ odor during the $Y$-maze test ( 5 trials). $\boldsymbol{B}$, Freezing to the conditioned odor presentations (cue test, 5 odor presentations). C, CORT levels immediately after odor- $0.5 \mathrm{~mA}$ shock conditioning. $\boldsymbol{D}-\mathbf{G},{ }^{14} \mathrm{C} 2-\mathrm{DG}$ autoradiography during odor- 0.5 $\mathrm{mA}$ shock conditioning in the olfactory bulb odor-specific loci of the glomerular layer $(\boldsymbol{D})$, lateral nucleus of the amygdala $(\boldsymbol{E})$, basolateral nucleus of the amygdala $(\boldsymbol{F})$, and central nucleus of the amygdala $(\boldsymbol{G}) .^{*} p<0.05$, significantly different from the other groups ( $n=5-8$ per group).

electrode. Neurochemical concentrations were estimated using chromatographic peak areas and calibration curves obtained with standard mixtures of known monoamine compounds. During the course of dialysate autoinjection fractions, a standard mixture was injected every fifth sample to monitor and correct calibration curves.

\section{Assessing neural correlates within the olfactory bulb and} the amygdala

P7 pups were injected with ${ }^{14} \mathrm{C} 2$-deoxyglucose (2-DG) $(20 \mu \mathrm{Ci} / 100 \mathrm{~g}$, s.c.) $5 \mathrm{~min}$ before the $45 \mathrm{~min}$ odor-shock conditioning. Immediately after conditioning, pups were decapitated, and their brains were quickly removed, frozen in 2 -methylbutane $\left(-45^{\circ} \mathrm{C}\right)$, and stored in a $-70^{\circ} \mathrm{C}$ freezer. Then, brains were sectioned $(20 \mu \mathrm{m})$ in a $-20^{\circ} \mathrm{C}$ cryostat, and every other section was saved to be placed on a coverslip and exposed for $5 \mathrm{~d}$ along with standards $\left({ }^{14} \mathrm{C}\right.$ standards $10 \times 0.02 \mathrm{mCi}$; American Radiolabeled Chemicals) to x-ray film (Coopersmith and Leon, 1986; Sullivan and Wilson, 1995). 
Olfactory bulb. The olfactory bulb does not require staining because anatomical landmarks are clearly visible with 2-DG, with odors producing an odor-specific pattern of 2-DG uptake within the glomerular layer of the olfactory bulb, which was expressed relative to the periventricular core of the bulb (Greer et al., 1982). These odor-specific loci, along with the periventricular core, were measured using quantitative optical densitometry with $\mathrm{NIH}$ Image software (Coopersmith and Leon, 1986; Sullivan and Leon, 1986). To quantify 2-DG uptake, the computer constructed a calibration curve that related the gray value of ${ }^{14} \mathrm{C}$ standards that were exposed with the brain sections to that of determined value. The autoradiographs were observed for the presence of odorspecific glomerular layer foci, which are several times above the background uptake (see Fig. 2F). Five readings were taken from the periventricular core and the odor-specific loci. Data were analyzed as the uptake within the odor-specific loci relative to the uptake in the periventricular core (Sullivan and Wilson, 1995). Analyses were made blind to conditioning groups.

Amygdala. Specific amygdala nuclei (central, basolateral, and lateral nuclei) were identified by counterstaining sections with cresyl violet and by making a template of that brain area for use with the autoradiographs. The 2-DG uptake was expressed relative to 2-DG uptake in the corpus callosum (which did not vary among conditioning groups) to control for differences in section thickness and exposure (see Fig. 2G) (Sullivan et al., 2000a,b). Three readings were taken from the central, lateral, and basolateral nuclei of the amygdala. Data were analyzed as the uptake within the central, lateral, and basolateral nuclei of the amygdala relative to the uptake in the corpus callosum (Sullivan and Wilson, 1995). Analyses were made blind to conditioning groups.

\section{Histology and drugs spread}

After behavioral testing, brains were removed and frozen in 2-methylbutane $\left(-45^{\circ} \mathrm{C}\right)$ and stored in a $-70^{\circ} \mathrm{C}$ freezer. For analysis, brains were sectioned $(20 \mu \mathrm{m})$ in a $-20^{\circ} \mathrm{C}$ cryostat, and cresyl violet staining was used to verify LC and amygdaloid complex cannulas placements. Cannula tracks are shown in Figures $3 D$ (amygdala) and $4 D$ (LC).

To characterize the extent of drug diffusion within and outside of the LC and the amygdaloid complex, additional pups were used. On P7, pups were anesthetized by urethane and placed in a stereotaxic apparatus. For the LC, holes were drilled through the skull at $1.4 \mathrm{~mm}$ posterior to lambda and $\pm 0.60 \mathrm{~mm}$ from the midline. A $10 \mu \mathrm{l}$ Hamilton syringe was lowered $5.5 \mathrm{~mm}$ from the surface of the skull, which placed the tip near the LC. The pups were infused with $2 \mu \mathrm{l}$ of a saline solution of $\left[{ }^{3} \mathrm{H}\right] \mathrm{CRH}$ $(0.37 \mu \mathrm{Ci} / \mu \mathrm{l}$; PerkinElmer Life and Analytical Sciences). For the amygdaloid complex, holes were drilled through the skull at $0.80 \mathrm{~mm}$ posterior to bregma and $\pm 3.00 \mathrm{~mm}$ from the midline. A $10 \mu \mathrm{l}$ Hamilton syringe was lowered $5.0 \mathrm{~mm}$ from the surface of the skull, which placed the tip near the amygdaloid complex. The pups were infused with $2 \mu \mathrm{l}$ of a saline solution of $\left[{ }^{3} \mathrm{H}\right] \mathrm{CORT}(1 \mu \mathrm{Ci} / \mu \mathrm{l}$; PerkinElmer Life and Analytical Sciences). Twenty minutes after infusion, the brains were quickly removed and frozen in methylbutane at $-45^{\circ} \mathrm{C}$. Brains were sliced in $20 \mu \mathrm{m}$ coronal sections. The slides were apposed to a tritium storage phosphor screen (GE Healthcare). After $14 \mathrm{~d}$ exposure, the screen was scanned at a pixel density of $50 \mu \mathrm{m}$ (5000 dots $\left./ \mathrm{cm}^{2}\right)$ with a STORM 820 Phosphor Imager (Molecular Dynamics). Phosphorimaging of the slides results in a TIFF image file (Tucker et al., 2002; Moriceau and Sullivan, 2004b; Moriceau et al., 2006).

\section{Statistical analysis}

Comparisons were made between groups using the ANOVA test, followed by post hoc Fisher's tests. In all cases, the level of significance was set at $p<0.05$ level.

\section{Results}

\section{Early-life stress effect on learning and neural circuit}

As shown in Figure $1 A$, at P7, normally reared paired odor-0.5 $\mathrm{mA}$ shock pups learned an odor preference, whereas stressedreared paired pups learned an avoidance. However, CORT antagonist injection in stressed-reared paired pups reinstated the learned odor preference. The Y-maze ANOVA revealed a main effect of rearing condition $\left(F_{(1,46)}=24.939, p<0.0005\right)$, a significant effect of conditioning group $\left(F_{(3,46)}=36.157, p<\right.$ $0.0001)$, and a significant interaction between conditioning group and rearing condition $\left(F_{(3,46)}=24.939, p<0.0001\right)$; post hoc Fisher's tests revealed that the stressed-reared paired groups differed significantly from the normally reared paired group and the stressed-reared paired pups receiving a CORT antagonist injection. Also, the normally reared paired group, the stressedreared paired pups receiving a CORT antagonist injection, and the stressed-reared paired groups each differed significantly from each of the control groups at the $p<0.05$ level.

Furthermore, as illustrated in Figure $1 B$, stressed-reared paired pups showed freezing compared with normally reared paired pups or stressed-reared paired pups receiving a CORT antagonist injection, which do not show freezing behavior. The freezing behavior ANOVA revealed a main effect of rearing condition $\left(F_{(1,32)}=66.016, p<0.0001\right)$, a significant effect of conditioning group $\left(F_{(3,32)}=81.926, p<0.0001\right)$, and a significant 
interaction between conditioning group and rearing condition $\left(F_{(3,32)}=66.016, p<0.0001\right)$; post hoc Fisher's tests revealed that the stressed-reared paired groups differed significantly from each of the control groups at the $p<0.05$ level.

Also, Figure $1 C$ shows that paired, unpaired, and odor-only pups exposed to stressed-rearing had increased levels of CORT compared with normally reared pups. ANOVA for the CORT levels revealed a significant main effect of rearing condition $\left(F_{(1,22)}=54.060, p<0.0005\right)$, a main effect of conditioning group $\left(F_{(1,22)}=4.298, p<0.05\right)$, and a significant interaction between conditioning group and rearing condition $\left(F_{(2,22)}=\right.$ $6.873, p<0.005)$; post hoc Fisher's tests revealed that the paired, unpaired, and odor-only stressed-reared pups were significantly different from the normally reared groups, although the paired, unpaired, and odor-only stressed-reared groups were also significantly different from one another at the $p<0.05$ level.

Figure $1 D$ illustrates an increased 2-DG uptake within the glomerular layer of the olfactory bulb of pups learning either an odor aversion (stressed-reared paired pups) or an odor preference (normally reared paired pups and stressed-reared paired pups receiving a CORT antagonist injection). No changes were observed in control groups. ANOVA revealed a main effect of conditioning group $\left(F_{(3,32)}=22.171, p<0.0001\right)$; post hoc Fisher's tests revealed that each of the paired groups were significantly different from each of the control groups.

As illustrated in Figure $1 E-G$, stressed rearing, which results in pups learning an odor aversion rather than the age-typical odor preference, produced odor-shock-induced enhanced 2-DG uptake in the lateral, basolateral, and central amygdala nuclei. CORT antagonist injection prevented the enhance amygdala 2-DG uptake. Specifically, central amygdala nucleus ANOVA revealed a significant main effect of conditioning group $\left(F_{(3,32)}=11.156, p<0.0001\right)$, a main effect of rearing condition $\left(F_{(1,32)}=6.243, p<0.05\right)$, and a significant interaction between conditioning group and rearing condition $\left(F_{(3,32)}=8.547, p<0.0005\right)$. The basolateral amygdala nucleus ANOVA revealed a significant main effect of conditioning group $\left(F_{(3,32)}=7.975, p<0.0005\right)$, a main effect of rearing condition $\left(F_{(1,32)}=10.215, p<0.005\right)$, and a significant interaction between conditioning group and rearing condition $\left(F_{(3,32)}=8.358, p<0.0005\right)$. The lateral amygdala nucleus ANOVA revealed a significant main effect of conditioning group $\left(F_{(3,32)}=8.827, p<0.0005\right)$, a main effect of rearing condition $\left(F_{(1,32)}=9.375, p<0.005\right)$, and a significant interaction between conditioning group and rearing condition $\left(F_{(3,32)}=9.484, p<0.0001\right)$; post hoc Fisher's tests revealed that basolateral, central, and lateral nucleus of the amygdala of stressed-reared paired pups differed from each of the other groups at the $p<0.05$ level.

\section{Mimicking stressed rearing by systemic CORT injection switches odor preference to odor aversion learning and alters the neural circuitry}

We have demonstrated previously that systemic CORT injection during odor- $0.5 \mathrm{~mA}$ shock conditioning switches odorpreference learning to odor aversion learning (Moriceau et al., 2006). Our goal here was to assess the effect of systemic CORT injection on the olfactory bulb and the participation of the amygdala (basolateral, lateral, and central nuclei) in learning and verify whether CORT injection was able to mimic the effect of early-life stress.

At P7, paired odor-shock pups injected with saline learned an odor preference (same as normally reared pups, experiment 1 ).

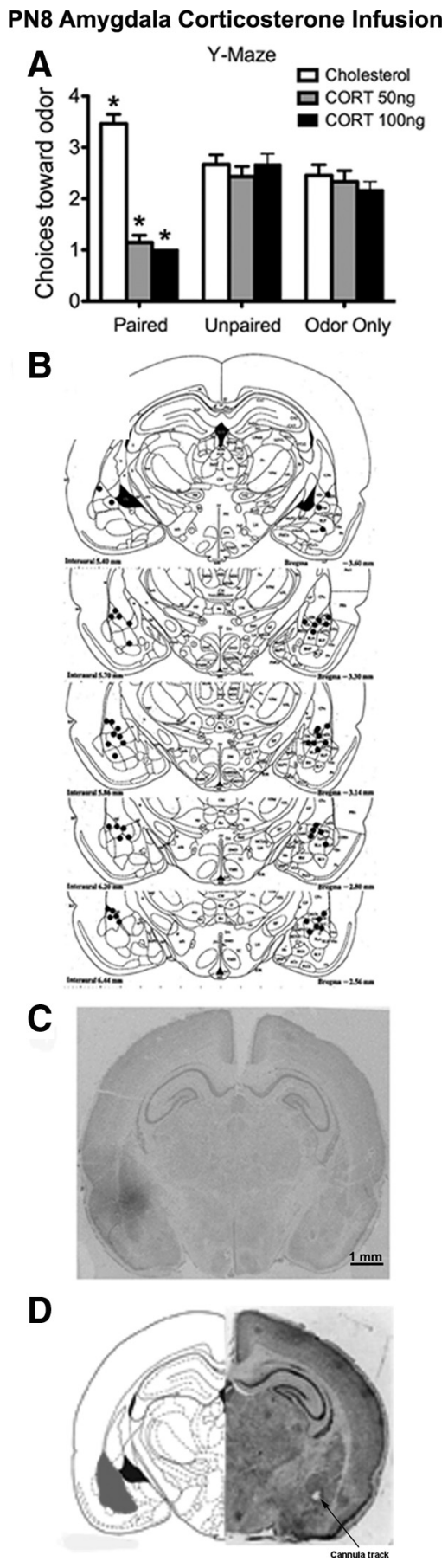

Figure 3. Odor- $0.5 \mathrm{~mA}$ shock conditioning in $\mathrm{P7}$ pups with intra-amygdala CORT infusion. $A$, Number of choices toward the CS odor in a Y-maze test. $\boldsymbol{B}$, Locations of cannula tips (solid circles) for rats used for CORT infusion into the amygdala (Paxinos et al., 1991). C, Brain section counterstained with cresyl violet illustrating the extent of $\left[{ }^{3} \mathrm{H}\right] \mathrm{CORT}$ diffusion within the amygdala. $\boldsymbol{D}$, Representative location of cannula tip near the basolateral complex of the amygdala. The cannula tip placement is marked by an arrow. The location of the basolateral complex of the amygdala is illustrated in gray ( $n=7-12$ per group). ${ }^{*} p<0.05$, significantly different from the other groups.

However, systemic CORT injection permitted pups to learn odor avoidance instead (similarly to stressed-reared pups, experiment 1) (Fig. $2 A$ ). The Y-maze ANOVA revealed a main effect of drug treatment $\left(F_{(1,34)}=22.514, p<0.0001\right)$ and a significant interaction between conditioning group and drug treatment $\left(F_{(2,34)}=\right.$ $23.849, p<0.0001)$; post hoc Fisher's tests revealed that the saline- 
paired group and the CORT-paired groups each differed significantly from each of the control groups and also from one another at the $p<0.05$ level.

Figure $2 B$ depicted an increased 2-DG uptake within the glomerular layer of the olfactory bulb of pups learning either an odor aversion (CORT-injected pups) or an odor preference (saline-injected pups). No changes were observed in control groups. ANOVA revealed a main effect of conditioning group $\left(F_{(5,22)}=23.507, p<\right.$ $0.0001)$; post hoc Fisher's tests revealed that each of the paired groups were significantly different from each control group.

As illustrated in Figure 2, C-E, CORT injection, which causes pups to learn an odor aversion rather than the age-typical odor preference, produced odor-shockinduced enhancement in basolateral and lateral amygdala nuclei 2-DG uptake. Specifically, basolateral nucleus ANOVA revealed a significant main effect of conditioning group $\left(F_{(2,23)}=12.597, p=\right.$ 0.0005), a main effect of drug treatment $\left(F_{(1,23)}=9.086, p<0.05\right)$, and a significant interaction between conditioning group and drug treatment $\left(F_{(2,23)}=\right.$ 6.287, $p<0.05)$. The lateral nucleus ANOVA revealed a significant main effect of conditioning group $\left(F_{(2,23)}=\right.$ 12.304, $p=0.0005)$, a main effect of drug treatment $\left(F_{(1,23)}=7.039, p<0.05\right)$, and a significant interaction between conditioning group and drug treatment $\left(F_{(2,23)}=3.927, p<0.05\right)$. The central nucleus ANOVA revealed a significant interaction between conditioning group and drug treatment $\left(\mathrm{F}_{(2,21)}=6.144, p<0.05\right)$; post hoc Fisher's tests revealed that basolateral, lateral, and central nuclei of the amygdala of paired CORT-injected pups differed from each of the other groups at $p<0.05$ level.

\section{CORT infusion into the amygdaloid complex and CRH} infusion into the LC permits odor aversion learning

Here we assess CORT action on the amygdala-LC axis during odor aversion learning with odor-shock conditioning. Specifically, we mimic the activation of the amygdala by CORT and the subsequent activation of the LC by central amygdala CRH afferents to permit the release of NE into the olfactory bulb.

As shown in Figure $3 A$, paired pups that received amygdala CORT infusions (50 or $100 \mathrm{ng}$ ) during odor-shock conditioning exhibited a subsequent odor aversion. ANOVA revealed a significant main effect of conditioning group $\left(F_{(2,67)}=10.525\right.$, $p=0.0001)$, a main effect of drug treatment $\left(F_{(2,67)}=24.899, p<\right.$ $0.0001)$, and a significant interaction between conditioning group and drug treatment $\left(F_{(4,67)}=17.966, p<0.0001\right)$; post hoc Fisher's tests revealed that paired pups infused with 50 or $100 \mathrm{ng}$ CORT, and paired pups infused with cholesterol into the amygdala each differed significantly from each of the control groups at the $p<0.05$ level. Amygdala cannula tip placements are shown in Figure $3 B$. All tip placements were $<1 \mathrm{~mm}$ from the basolateral complex of the amygdala. As demonstrated in Figure $3 C$, most of the drug diffusion was limited to the amygdala, most notably the

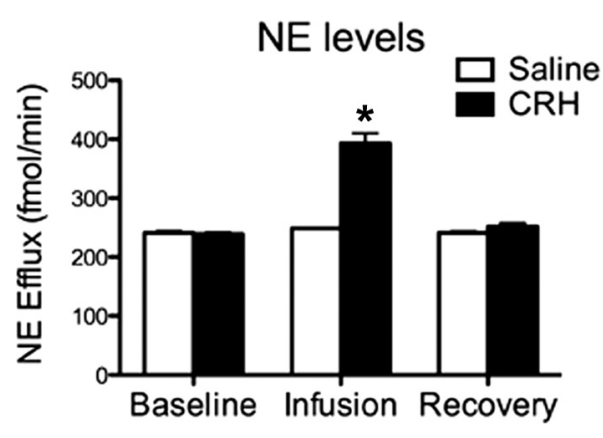

Figure 5. Effect of CRH infusion into the $L C$ on the level of NE measured by microdialysis and $\mathrm{HPLC}$ in the olfactory bulb of sensitive-period pups (P7). ${ }^{*} p<0.05$, significantly different from the other groups.

lateral and central nuclei. However, some drug spread was found $\sim 1 \mathrm{~mm}$ outside the amygdala.

As shown in Figure 4A, paired pups that received 100 or 200 ng CRH infused into the LC during odor-shock conditioning exhibited an odor aversion, whereas $50 \mathrm{ng}$ CRH infusion prevented the odor-preference learning in paired pups. ANOVA revealed a significant effect of drug treatment $\left(F_{(3,76)}=6.182, p<0.001\right)$ and a significant interaction between conditioning group and drug treatment $\left(F_{(6,76)}=10.537, p<0.001\right)$; post hoc Fisher's tests revealed that LC CRH 100 and 200 ng paired pups and LC paired saline pups each differed significantly from each of the control groups at the $p<0.05$ level. Cannula tip placements directed at the LC, which were all $<1 \mathrm{~mm}$ from the LC, are shown in Figure $4 B$. Among our cannulated animals, two paired pups that received $100 \mathrm{ng}$ of $\mathrm{CRH}$ had misplaced cannula, and they did 
PREFERENCE LEARNING

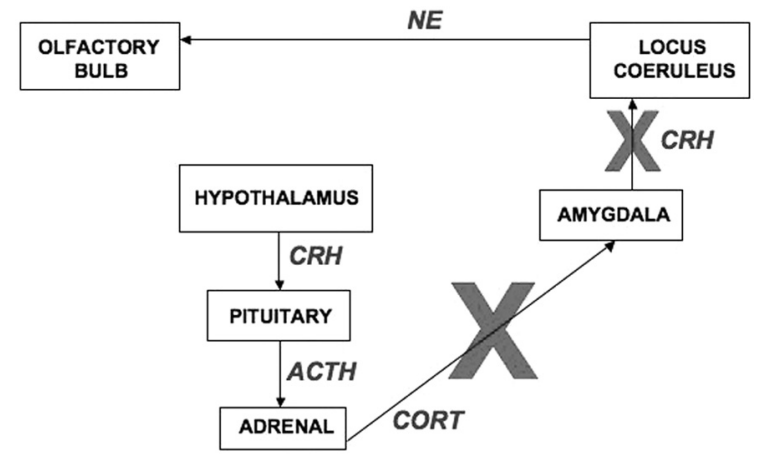

AVERSION LEARNING

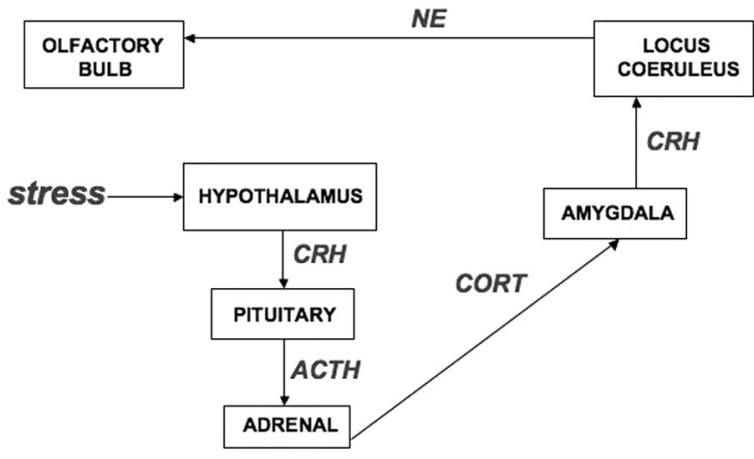

Figure 6. Schematic illustrating the normal pathway activated by odor-preference learning and the pathway activated by chronic stress. Specifically, chronic stress activates the hypothalamus-pituitary-adrenal axis to release CORT. Consequently, the action of this blood-borne CORT on the amygdala permits CRH release from amygdala efferents to the $L C$, which releases NE directly into the olfactory bulb.

not show the aversive behaviors. As demonstrated in Figure $4 C$, the volume of drugs infused into the LC diffused $<1 \mathrm{~mm}$ from the LC.

\section{CRH infusion into the LC increases olfactory bulb NE}

Figure 5 showed that CRH infusion alone into the LC increases NE levels in the olfactory bulb, whereas saline infusion alone does not change NE levels. ANOVA for NE levels revealed a significant main effect of drug treatments $\left(F_{(1,42)}=96.956, p<0.0001\right)$, a main effect of time $\left(F_{(7,42)}=50.938, p<0.0001\right)$, and a significant interaction between drug treatments and time $\left(F_{(7,42)}=\right.$ 41.414, $p<0.0001)$; post hoc Fisher's tests revealed that the CRH infusion differed significantly from saline infusion and from the baseline levels at the $p<0.05$ level.

No significant differences between groups were found for NE metabolites or basal level of NE over the $2 \mathrm{~h}$ baseline.

\section{Discussion}

Our data suggests that early-life stress compromises social behavior and attachment via a unique cascade of neural events. Specifically, the attachment odor learning combined with stress produces dual activation of the attachment circuit (LC-olfactory bulb) together with the fear circuit (amygdala), which results in behavioral aversion to an odor rather than the age-appropriate approach. We suggest a neural pathway (Fig. 6) to accommodate the dual activation of the attachment and fear systems. The potential pathway to support this combined fear/attachment learning circuit involves a cascade of events beginning with CORT release in response to stress. This activates the amygdala support- ing aversion/fear learning, that will excite the LC via CRH afferents from the amygdala and increases olfactory bulb NE that would typically support preference learning. Each step in this cascade is described in more detail below. Importantly, this dual activation of the attachment and fear circuit was also activated in pups reared by a stressed mother that handled pups roughly during mother-infant interactions (i.e., mother steps on pups leaving/entering the nest). Although pups within the nest do not avoid the mother and show normal weight gain, they do spend less time in contact with the mother and nursing (see Table 1).

\section{Activation of the fear circuit}

During the sensitive period, pups exhibit attenuated odor aversion learning supported by the failure of the amygdala to participate in learning (Sullivan et al., 2000a; Moriceau and Sullivan, 2006; Moriceau et al., 2006). Indeed, the infant amygdala does not exhibit learning-induced plasticity, nor does temporary suppression of the amygdala influence learning until P10. However, CORT injection permitted precocious odor aversion learning concurrently with increased amygdala 2-DG uptake (Moriceau and Sullivan, 2006; Moriceau et al., 2006). This is in sharp contrast to older pups and adult animals, in which the amygdala has a critical role in fear conditioning (Cousens and Otto, 1998; Cahill et al., 1999; Doron and LeDoux, 1999; Fanselow and LeDoux, 1999; Sullivan et al., 2000a; Schafe et al., 2001; Wallace and Rosen, 2001; Fanselow and Gale, 2003; Maren, 2003; McGaugh, 2004; Moriceau and Sullivan, 2006; Moriceau et al., 2006; Sevelinges et al., 2007; Rodrigues et al., 2009). Furthermore, systemic CORT injection, direct administration of CORT into the amygdala, or exposure to a psychological stressor increases the expression of CRH mRNA in the central amygdala in adult rats and increases the fear conditioned response in adult (Grino et al., 1989; Makino et al., 1994; Hatalski et al., 1998; Hsu et al., 1998; Merali et al., 1998; Shepard et al., 2000; Schmidt et al., 2004; Thompson et al., 2004; Myers et al., 2005; Vazquez et al., 2006; Korosi and Baram, 2008). Although CRH is a neuropeptide displaying a broad extrahypothalamic distribution (Bittencourt and Sawchenko, 2000) and CRH interacts with noradrenergic mechanisms in the basolateral complex of the amygdala (Roozendaal et al., 2008), a $\mathrm{CRH}$ connection also exists between the amygdala and the LC as shown by $\mathrm{CRH}$ neurons from the central nucleus of the amygdala projecting directly to the rostrolateral peri-LC (Valentino et al., 1992; Lehnert et al., 1998; Van Bockstaele et al., 1998, 1999, 2001; Koob and Heinrichs, 1999; Lechner and Valentino, 1999; Bouret et al., 2003; Reyes et al., 2006; Valentino and Van Bockstaele, 2008). Here, we showed that, during the sensitive period, earlylife stress (stressed-reared or CORT-injected pups) permits precocious activation of the amygdala and perhaps precocious activation of $\mathrm{CRH}$.

\section{Activation of the attachment circuit}

Sensitive-period pups exhibit enhanced odor-preference learning supported by a hyperfunctioning LC resulting in elevated levels of olfactory bulb NE. Indeed, NE from the LC is required for the neural plasticity of the olfactory bulb and attachment learning. Specifically, in pups, pairing an odor with a moderate level of $\mathrm{NE}(2 \mathrm{mg} / \mathrm{kg})$ supports odor-preference learning, whereas a higher dose $(4 \mathrm{mg} / \mathrm{kg}$ ) produces an odor aversion (Sullivan and Leon, 1986; Sullivan et al., 1989, 1991; Yuan et al., 2000; Harley et al., 2006; Christie-Fougere et al., 2009).

Attachment circuit activation presumably involves the unique neonatal LC response characteristics. Indeed, developmental differences in LC activity are reflected during both noxious (electric 
shock) and non-noxious (stroking) stimulus-evoked NE release in the olfactory bulb, with neonatal pups releasing significantly more NE than older pups/adult (Kimura and Nakamura, 1987; Nakamura et al., 1987; Nakamura and Sakaguchi, 1990; McLean and Shipley, 1991; Sullivan et al., 1992, 2000b; Sullivan and Wilson, 1994; Langdon et al., 1997; Yuan et al., 2000). The mechanism for the prolonged neonatal LC response appears because of the lack of functional $\alpha 2$ inhibitory noradrenergic autoreceptors that terminate the LC response in older pups/adult (Nakamura et al., 1987; Pieribone et al., 1994; Scheinin et al., 1994; Winzer-Serhan et al., 1999).

In contrast, in older pups and adults, the LC has different characteristics limiting NE release that is associated with $\alpha 2$ inhibitory autoreceptor functional emergence (Nakamura et al., 1987; Nakamura and Sakaguchi, 1990; Scheinin et al., 1994). This NE level decrease is responsible for the termination of the sensitive period in pups' NE-dependent rapid odor-preference learning (Moriceau and Sullivan, 2004b). Furthermore, as described above, the LC is activated via CRH afferent from the amygdala during stress in adults. Indeed, CRH antagonist application into the LC prevents fear conditioning (Bouret et al., 2003), whereas CRH administered locally into the adult LC is able to increase the fear response (Valentino et al., 1983; Dunn and Everitt, 1987; Butler et al., 1990; Emoto et al., 1993; Borsody and Weiss, 1996; Curtis et al., 1997; Page and Abercrombie, 1999; Bouret et al., 2003; Dunn et al., 2004; Jedema and Grace, 2004; Reyes et al., 2006; Dunn and Swiergiel, 2008). This increase in fear response is associated with a firing rate increase of the LC NE neurons and application of $\mathrm{CRH}$ antagonist into the LC blocked this effect. Here, we showed that, during the sensitive period, early-life stress (stressed-reared or CORT-injected paired pups) increases olfactory bulb 2-DG uptake. Furthermore, $\mathrm{CRH}$ infusion directly into the LC permits odor aversion learning associated with a large NE increase into the olfactory bulb-probably the consequence of too much NE into the bulb attributable to the unique neonatal LC response characteristics. Therefore, our data suggest that the 2-DG increase is not attributable to the activation of the attachment circuit per se but to the infant's unique hyperfunctioning LC being stimulated by CRH. However, because of the incompletely defined NE pathway between the LC, amygdala, and $\mathrm{A}_{1} / \mathrm{A}_{2}$ noradrenergic nuclei, other potential pathways cannot be eliminated, including NE feedback to the basolateral nucleus of the amygdala.

\section{Pup behavior and neural changes: early-life stress and elevated CORT}

The present results, together with results from the Baram laboratory (Gilles et al., 1996; Avishai-Eliner et al., 2001), suggest that elevation of CORT on pups' behavior leads to disruption of social interactions with the mother, as well as learning about the mother. These disruptions in behavior are presumably because of neural changes within the amygdala and LC (Avishai-Eliner et al., 2001; Brunson et al., 2005; Levine, 2005; Guijarro et al., 2007; Champagne et al., 2008; McEwen, 2008; Cirulli et al., 2009; Lupien et al., 2009). The present data suggest that the effects of early stress on the infants' LC and amygdala have immediate consequences for pups' interactions with the mother via disruption in attachment.

As demonstrated previously, early-life stress alters the developmental trajectory of myriad brain areas, including the amygdala and LC, with elevated CORT implicated as a causal factor (Caldji et al., 1998; Dent et al., 2001; Sanchez et al., 2001; Plotsky et al., 2005; Champagne et al., 2008; McEwen, 2008; Cirulli et al.,
2009; Lupien et al., 2009). The maternal stress procedure used here, which is based on the insufficient nest/bedding paradigm developed in the Baram laboratory, also produces an increase in pups' CORT through maternal rough handling of pups (Gilles et al., 1996; Avishai-Eliner et al., 2001). This precocious increase in CORT is significant because it indicates that early-life stress prematurely ends the stress hyporesponsive period, which is characterized by pups' low basal CORT levels and the failure to mount the stress-induced CORT release (Rosenfeld et al., 1992; Grino et al., 1994; Levine, 2001).

\section{Implications}

Early-life stress seems to manipulate the precise timing for the participation of specific brain regions in learning. Specifically, these data suggest the fear circuit (amygdala-CORT LC-CRH) is coactivated with the attachment circuit (LC-NE-olfactory bulb). Because early-life activation of LC CRH has been linked with later-life behavioral and neural deficits, these data may suggest a very specific route of activation during early-life pain, which is blocked without stress. Furthermore, this attachment/fear circuit overlaps with neural correlates of compromised mental health, including depression and anxiety in humans (Heim et al., 2001; Nestler et al., 2002; Teicher et al., 2003; Gunnar et al., 2009; Lupien et al., 2009). Overall, there is remarkable convergence between this new early-life stress paradigm and other paradigms, as well as the clinical literature (Kaufman, 1991; Kaufman et al., 1997; Caldji et al., 1998; Lehnert et al., 1998; Glaser, 2000; Dent et al., 2001; Kaufman and Charney, 2001; Sanchez et al., 2001; Grossman et al., 2003; Teicher et al., 2003; Plotsky et al., 2005; Gunnar and Quevedo, 2007; Cirulli et al., 2009).

\section{References}

Avishai-Eliner S, Gilles EE, Eghbal-Ahmadi M, Bar-El Y, Baram TZ (2001) Altered regulation of gene and protein expression of hypothalamicpituitary-adrenal axis components in an immature rat model of chronic stress. J Neuroendocrinol 13:799-807.

Bittencourt JC, Sawchenko PE (2000) Do centrally administered neuropeptides access cognate receptors?: an analysis in the central corticotropinreleasing factor system. J Neurosci 20:1142-1156.

Borsody MK, Weiss JM (1996) Influence of corticotropin-releasing hormone on electrophysiological activity of locus coeruleus neurons. Brain Res 724:149-168.

Bouret S, Duvel A, Onat S, Sara SJ (2003) Phasic activation of locus ceruleus neurons by the central nucleus of the amygdala. J Neurosci 23:3491-3497.

Brunjes PC, Alberts JR (1979) Olfactory stimulation induces filial preferences for huddling in rat pups. J Comp Physiol Psychol 93:548-555.

Brunson KL, Kramár E, Lin B, Chen Y, Colgin LL, Yanagihara TK, Lynch G, Baram TZ (2005) Mechanisms of late-onset cognitive decline after early-life stress. J Neurosci 25:9328-9338.

Butler PD, Weiss JM, Stout JC, Nemeroff CB (1990) Corticotropinreleasing factor produces fear-enhancing and behavioral activating effects following infusion into the locus coeruleus. J Neurosci 10:176-183.

Cahill L, Weinberger NM, Roozendaal B, McGaugh JL (1999) Is the amygdala a locus of "conditioned fear"? Some questions and caveats. Neuron 23:227-228.

Caldji C, Tannenbaum B, Sharma S, Francis D, Plotsky PM, Meaney MJ (1998) Maternal care during infancy regulates the development of neural systems mediating the expression of fearfulness in the rat. Proc Natl Acad Sci U S A 95:5335-5340.

Camp LL, Rudy JW (1988) Changes in the categorization of appetitive and aversive events during postnatal development of the rat. Dev Psychobiol 21:25-42.

Campbell BA (1984) Reflections on the ontogeny of learning and memory. In: Comparative perspectives on the development of memory (Kail R, Spear NE, eds), pp 23-35. Hillsdale, NJ: Erlbaum.

Champagne DL, Bagot RC, van Hasselt F, Ramakers G, Meaney MJ, de Kloet ER, Joëls M, Krugers H (2008) Maternal care and hippocampal plastic- 
ity: evidence for experience-dependent structural plasticity, altered synaptic functioning, and differential responsiveness to glucocorticoids and stress. J Neurosci 28:6037-6045.

Christie-Fougere MM, Darby-King A, Harley CW, McLean JH (2009) Calcineurin inhibition eliminates the normal inverted $U$ curve, enhances acquisition and prolongs memory in a mammalian $3^{\prime}-5^{\prime}$-cyclic AMPdependent learning paradigm. Neuroscience 158:1277-1283.

Cirulli F, Francia N, Berry A, Aloe L, Alleva E, Suomi SJ (2009) Early life stress as a risk factor for mental health: role of neurotrophins from rodents to non-human primates. Neurosci Biobehav Rev 33:573-585.

Coopersmith R, Leon M (1986) Enhanced neural response by adult rats to odors experienced early in life. Brain Res 371:400-403.

Cousens G, Otto T (1998) Both pre- and posttraining excitotoxic lesions of the basolateral amygdala abolish the expression of olfactory and contextual fear conditioning. Behav Neurosci 112:1092-1103.

Curtis AL, Lechner SM, Pavcovich LA, Valentino RJ (1997) Activation of the locus coeruleus noradrenergic system by intracoerulear microinfusion of corticotropin-releasing factor: effects on discharge rate, cortical norepinephrine levels and cortical electroencephalographic activity. J Pharmacol Exp Ther 281:163-172.

De Bellis MD (2005) The psychobiology of neglect. Child Maltreat 10:150-172.

Dent GW, Smith MA, Levine S (2001) Stress-induced alterations in locus coeruleus gene expression during ontogeny. Brain Res Dev Brain Res 127:23-30.

Doron NN, LeDoux JE (1999) Organization of projections to the lateral amygdala from auditory and visual areas of the thalamus in the rat. J Comp Neurol 412:383-409.

Dunn AJ, Swiergiel AH (2008) The role of corticotropin-releasing factor and noradrenaline in stress-related responses, and the inter-relationships between the two systems. Eur J Pharmacol 583:186-193.

Dunn AJ, Swiergiel AH, Palamarchouk V (2004) Brain circuits involved in corticotropin-releasing factor-norepinephrine interactions during stress. Ann N Y Acad Sci 1018:25-34.

Dunn LT, Everitt BJ (1987) The effects of lesions to noradrenergic projections from the locus coeruleus and lateral tegmental cell groups on conditioned taste aversion in the rat. Behav Neurosci 101:409-422.

Emoto H, Tanaka M, Koga C, Yokoo H, Tsuda A, Yoshida M (1993) Corticotropin-releasing factor activates the noradrenergic neuron system in the rat brain. Pharmacol Biochem Behav 45:419-422.

Fanselow MS, Gale GD (2003) The amygdala, fear, and memory. Ann N Y Acad Sci 985:125-134.

Fanselow MS, LeDoux JE (1999) Why we think plasticity underlying Pavlovian fear conditioning occurs in the basolateral amygdala. Neuron 23:229-232.

Galef BG Jr, Kaner HC (1980) Establishment and maintenance of preference for natural and artificial olfactory stimuli in juvenile rats. J Comp Physiol Psychol 94:588-595.

Gilles EE, Schultz L, Baram TZ (1996) Abnormal corticosterone regulation in an immature rat model of continuous chronic stress. Pediatr Neurol 15:114-119.

Glaser D (2000) Child abuse and neglect and the brain: a review. J Child Psychol Psychiatry 41:97-116.

Greer CA, Stewart WB, Teicher MH, Shepherd GM (1982) Functional development of the olfactory bulb and a unique glomerular complex in the neonatal rat. J Neurosci 2:1744-1759.

Grino M, Young WS 3rd, Burgunder JM (1989) Ontogeny of expression of the corticotropin-releasing factor gene in the hypothalamic paraventricular nucleus and of the proopiomelanocortin gene in rat pituitary. Endocrinology 124:60-68.

Grino M, Paulmyer-Lacroix O, Faudon M, Renard M, Anglade G (1994) Blockade of alpha 2-adrenoceptors stimulates basal and stress-induced adrenocorticotropin secretion in the developing rat through a central mechanism independent from corticotropin-releasing factor and arginine vasopressin. Endocrinology 135:2549-2557.

Grossman AW, Churchill JD, McKinney BC, Kodish IM, Otte SL, Greenough WT (2003) Experience effects on brain development: possible contributions to psychopathology. J Child Psychol Psychiatry 44:33-63.

Guijarro JZ, Tiba PA, Ferreira TL, Kawakami SE, Oliveira MG, Suchecki D (2007) Effects of brief and long maternal separations on the HPA axis activity and the performance of rats on context and tone fear conditioning. Behav Brain Res 184:101-108.
Gunnar M, Quevedo K (2007) The neurobiology of stress and development. Annu Rev Psychol 58:145-173.

Gunnar MR, Frenn K, Wewerka SS, Van Ryzin MJ (2009) Moderate versus severe early life stress: associations with stress reactivity and regulation in 10-12-year-old children. Psychoneuroendocrinology 34:62-75.

Hall WG (1979) Feeding and behavioral activation in infant rats. Science 205:206-209.

Harley CW, Darby-King A, McCann J, McLean JH (2006) Beta1adrenoceptor or alphal-adrenoceptor activation initiates early odor preference learning in rat pups: support for the mitral cell/cAMP model of odor preference learning. Learn Mem 13:8-13.

Haroutunian V, Campbell BA (1979) Emergence of interoceptive and exteroceptive control of behavior in rats. Science 205:927-929.

Hatalski CG, Guirguis C, Baram TZ (1998) Corticotropin releasing factor mRNA expression in the hypothalamic paraventricular nucleus and the central nucleus of the amygdala is modulated by repeated acute stress in the immature rat. J Neuroendocrinol 10:663-669.

Heim C, Newport DJ, Bonsall R, Miller AH, Nemeroff CB (2001) Altered pituitary-adrenal axis responses to provocative challenge tests in adult survivors of childhood abuse. Am J Psychiatry 158:575-581.

Hsu DT, Chen FL, Takahashi LK, Kalin NH (1998) Rapid stress-induced elevations in corticotropin-releasing hormone mRNA in rat central amygdala nucleus and hypothalamic paraventricular nucleus: an in situ hybridization analysis. Brain Res 788:305-310.

Hunt P, Campbell BA (1999) Developmental dissociation of the components of conditioned fear. In: Learning, motivation, and cognition: the functional behaviorism of Robert C. Bolles (Bouton ME, Fanselow MS, eds). Washington, DC: American Psychological Association.

Jedema HP, Grace AA (2004) Corticotropin-releasing hormone directly activates noradrenergic neurons of the locus ceruleus recorded in vitro. J Neurosci 24:9703-9713.

Kaufman J (1991) Depressive disorders in maltreated children. J Am Acad Child Adolesc Psychiatry 30:257-265.

Kaufman J, Charney D (2001) Effects of early stress on brain structure and function: implications for understanding the relationship between child maltreatment and depression. Dev Psychopathol 13:451-471.

Kaufman J, Birmaher B, Perel J, Dahl RE, Moreci P, Nelson B, Wells W, Ryan ND (1997) The corticotropin-releasing hormone challenge in depressed abused, depressed nonabused, and normal control children. Biol Psychiatry 42:669-679.

Kimura F, Nakamura S (1987) Postnatal development of alpha-adrenoceptormediated autoinhibition in the locus coeruleus. Brain Res 432:21-26.

Koob GF (1999) Corticotropin-releasing factor, norepinephrine, and stress. Biol Psychiatry 46:1167-1180.

Koob GF, Heinrichs SC (1999) A role for corticotropin releasing factor and urocortin in behavioral responses to stressors. Brain Res 848:141-152.

Korosi A, Baram TZ (2008) The central corticotropin releasing factor system during development and adulthood. Eur J Pharmacol 583:204-214.

Langdon PE, Harley CW, McLean JH (1997) Increased beta adrenoceptor activation overcomes conditioned olfactory learning deficits induced by serotonin depletion. Brain Res Dev Brain Res 102:291-293.

Lechner SM, Valentino RJ (1999) Glucocorticoid receptor-immunoreactivity in corticotrophin-releasing factor afferents to the locus coeruleus. Brain Res 816:17-28.

Lehnert H, Schulz C, Dieterich K (1998) Physiological and neurochemical aspects of corticotropin-releasing factor actions in the brain: the role of the locus coeruleus. Neurochem Res 23:1039-1052.

Levine S (2001) Primary social relationships influence the development of the hypothalamic-pituitary-adrenal axis in the rat. Physiol Behav 73:255-260.

Levine S (2005) Developmental determinants of sensitivity and resistance to stress. Psychoneuroendocrinology 30:939-946.

Lupien SJ, McEwen BS, Gunnar MR, Heim C (2009) Effects of stress throughout the lifespan on the brain, behaviour and cognition. Nat Rev Neurosci 10:434-445.

Makino S, Gold PW, Schulkin J (1994) Corticosterone effects on corticotropinreleasing hormone mRNA in the central nucleus of the amygdala and the parvocellular region of the paraventricular nucleus of the hypothalamus. Brain Res 640:105-112.

Maren S (2003) The amygdala, synaptic plasticity, and fear memory. Ann N Y Acad Sci 985:106-113.

McEwen BS (2008) Central effects of stress hormones in health and disease: 
Understanding the protective and damaging effects of stress and stress mediators. Eur J Pharmacol 583:174-185.

McGaugh JL (2004) The amygdala modulates the consolidation of memories of emotionally arousing experiences. Annu Rev Neurosci 27:1-28.

McLean JH, Shipley MT (1991) Postnatal development of the noradrenergic projection from locus coeruleus to the olfactory bulb in the rat. J Comp Neurol 304:467-477.

Merali Z, McIntosh J, Kent P, Michaud D, Anisman H (1998) Aversive and appetitive events evoke the release of corticotropin-releasing hormone and bombesin-like peptides at the central nucleus of the amygdala. J Neurosci 18:4758-4766.

Moriceau S, Sullivan RM (2004a) Corticosterone influences on mammalian neonatal sensitive-period learning. Behav Neurosci 118:274-281.

Moriceau S, Sullivan RM (2004b) Unique neural circuitry for neonatal olfactory learning. J Neurosci 24:1182-1189.

Moriceau S, Sullivan RM (2006) Maternal presence serves as a switch between learning fear and attraction in infancy. Nat Neurosci 9:1004-1006.

Moriceau S, Roth TL, Okotoghaide T, Sullivan RM (2004) Corticosterone controls the developmental emergence of fear and amygdala function to predator odors in infant rat pups. Int J Dev Neurosci 22:415-422.

Moriceau S, Wilson DA, Levine S, Sullivan RM (2006) Dual circuitry for odor-shock conditioning during infancy: corticosterone switches between fear and attraction via amygdala. J Neurosci 26:6737-6748.

Myers DA, Gibson M, Schulkin J, Greenwood Van-Meerveld B (2005) Corticosterone implants to the amygdala and type $1 \mathrm{CRH}$ receptor regulation: effects on behavior and colonic sensitivity. Behav Brain Res 161:39-44.

Nakamura S, Sakaguchi T (1990) Development and plasticity of the locus coeruleus: a review of recent physiological and pharmacological experimentation. Prog Neurobiol 34:505-526.

Nakamura S, Kimura F, Sakaguchi T (1987) Postnatal development of electrical activity in the locus ceruleus. J Neurophysiol 58:510-524.

Nestler EJ, Barrot M, DiLeone RJ, Eisch AJ, Gold SJ, Monteggia LM (2002) Neurobiology of depression. Neuron 34:13-25.

Page ME, Abercrombie ED (1999) Discrete local application of corticotropinreleasing factor increases locus coeruleus discharge and extracellular norepinephrine in rat hippocampus. Synapse 33:304-313.

Paxinos G, Tork I, Tecott L, Valentino K (1991) Atlas of the developing rat brain. San Diego: Academic.

Pieribone VA, Nicholas AP, Dagerlind A, Hökfelt T (1994) Distribution of $\alpha 1$ adrenoceptors in rat brain revealed by in situ hybridization experiments utilizing subtype-specific probes. J Neurosci 14:4252-4268.

Plotsky PM, Thrivikraman KV, Nemeroff CB, Caldji C, Sharma S, Meaney MJ (2005) Long-term consequences of neonatal rearing on central corticotropin-releasing factor systems in adult male rat offspring. Neuropsychopharmacology 30:2192-2204.

Rangel S, Leon M (1995) Early odor preference training increases olfactory bulb norepinephrine. Brain Res Dev Brain Res 85:187-191.

Reyes BA, Fox K, Valentino RJ, Van Bockstaele EJ (2006) Agonist-induced internalization of corticotropin-releasing factor receptors in noradrenergic neurons of the rat locus coeruleus. Eur J Neurosci 23:2991-2998.

Richardson R, Paxinos G, Lee J (2000) The ontogeny of conditioned odor potentiation of startle. Behav Neurosci 114:1167-1173.

Rodrigues SM, LeDoux JE, Sapolsky RM (2009) The influence of stress hormones on fear circuitry. Annu Rev Neurosci 32:289-313.

Roozendaal B, Schelling G, McGaugh JL (2008) Corticotropin-releasing factor in the basolateral amygdala enhances memory consolidation via an interaction with the beta-adrenoceptor-cAMP pathway: dependence on glucocorticoid receptor activation. J Neurosci 28:6642-6651.

Rosenfeld P, Suchecki D, Levine S (1992) Multifactorial regulation of the hypothalamic-pituitary-adrenal axis during development. Neurosci Biobehav Rev 16:553-568.

Roth TL, Sullivan RM (2005) Memory of early maltreatment: Neonatal behavioral and neural correlates of maternal maltreatment within the context of classical conditioning. Biol Psychiatry 57:823-831.

Sánchez MM, Ladd CO, Plotsky PM (2001) Early adverse experience as a developmental risk factor for later psychopathology: evidence from rodent and primate models. Dev Psychopathol 13:419-449.

Schafe GE, Nader K, Blair HT, LeDoux JE (2001) Memory consolidation of Pavlovian fear conditioning: a cellular and molecular perspective. Trends Neurosci 24:540-546.

Scheinin M, Lomasney JW, Hayden-Hixson DM, Schambra UB, Caron MG, Lefkowitz RJ, Fremeau RT Jr (1994) Distribution of alpha 2-adrenergic receptor subtype gene expression in rat brain. Brain Res Mol Brain Res 21:133-149.

Schmidt M, Enthoven L, van Woezik JH, Levine S, de Kloet ER, Oitzl MS (2004) The dynamics of the hypothalamic-pituitary-adrenal axis during maternal deprivation. J Neuroendocrinol 16:52-57.

Sevelinges Y, Moriceau S, Holman P, Miner C, Muzny K, Gervais R, Mouly AM, Sullivan RM (2007) Enduring effects of infant memories: infant odor-shock conditioning attenuates amygdala activity and adult fear conditioning. Biol Psychiatry 62:1070-1079.

Shepard JD, Barron KW, Myers DA (2000) Corticosterone delivery to the amygdala increases corticotropin-releasing factor mRNA in the central amygdaloid nucleus and anxiety-like behavior. Brain Res 861:288-295.

Shipley MT, Halloran FJ, de la Torre J (1985) Surprisingly rich projection from locus coeruleus to the olfactory bulb in the rat. Brain Res 329:294-299.

Smith MA, Kim SY, van Oers HJ, Levine S (1997) Maternal deprivation and stress induce immediate early genes in the infant rat brain. Endocrinology 138:4622-4628.

Sullivan RM, Leon M (1986) Early olfactory learning induces an enhanced olfactory bulb response in young rats. Brain Res 392:278-282.

Sullivan RM, Wilson DA (1991) Neural correlates of conditioned odor avoidance in infant rats. Behav Neurosci 105:307-312.

Sullivan RM, Wilson DA (1994) The locus coeruleus, norepinephrine, and memory in newborns. Brain Res Bull 35:467-472.

Sullivan RM, Wilson DA (1995) Dissociation of behavioral and neural correlates of early associative learning. Dev Psychobiol 28:213-219.

Sullivan RM, Hofer MA, Brake SC (1986) Olfactory-guided orientation in neonatal rats is enhanced by a conditioned change in behavioral state. Dev Psychobiol 19:615-623.

Sullivan RM, Wilson DA, Leon M (1989) Norepinephrine and learninginduced plasticity in infant rat olfactory system. J Neurosci 9:3998-4006.

Sullivan RM, Wilson DA, Wong R, Correa A, Leon M (1990) Modified behavioral and olfactory bulb responses to maternal odors in preweanling rats. Brain Res Dev Brain Res 53:243-247.

Sullivan RM, McGaugh JL, Leon M (1991) Norepinephrine-induced plasticity and one-trial olfactory learning in neonatal rats. Brain Res Dev Brain Res 60:219-228.

Sullivan RM, Zyzak DR, Skierkowski P, Wilson DA (1992) The role of olfactory bulb norepinephrine in early olfactory learning. Brain Res Dev Brain Res 70:279-282.

Sullivan RM, Landers M, Yeaman B, Wilson DA (2000a) Good memories of bad events in infancy. Nature 407:38-39.

Sullivan RM, Stackenwalt G, Nasr F, Lemon C, Wilson DA (2000b) Association of an odor with activation of olfactory bulb noradrenergic beta-receptors or locus coeruleus stimulation is sufficient to produce learned approach responses to that odor in neonatal rats. Behav Neurosci 114:957-962.

Takahashi LK (1994) Organizing action of corticosterone on the development of behavioral inhibition in the preweanling rat. Brain Res Dev Brain Res 81:121-127.

Teicher MH, Andersen SL, Polcari A, Anderson CM, Navalta CP, Kim DM (2003) The neurobiological consequences of early stress and childhood maltreatment. Neurosci Biobehav Rev 27:33-44.

Thompson BL, Erickson K, Schulkin J, Rosen JB (2004) Corticosterone facilitates retention of contextually conditioned fear and increases CRH mRNA expression in the amygdala. Behav Brain Res 149:209-215.

Tucker DL, Tucker N, Conway T (2002) Gene expression profiling of the $\mathrm{pH}$ response in Escherichia coli. J Bacteriol 184:6551-6558.

Valentino RJ, Foote SL, Aston-Jones G (1983) Corticotropin-releasing factor activates noradrenergic neurons of the locus coeruleus. Brain Res 270:363-367.

Valentino RJ, Page M, Van Bockstaele E, Aston-Jones G (1992) Corticotropinreleasing factor innervation of the locus coeruleus region: distribution of fibers and sources of input. Neuroscience 48:689-705.

Valentino RJ, Van Bockstaele E (2008) Convergent regulation of locus coeruleus activity as an adaptive response to stress. Eur J Pharmacol 583:194-203.

Van Bockstaele EJ, Colago EE, Valentino RJ (1998) Amygdaloid corticotropinreleasing factor targets locus coeruleus dendrites: substrate for the co-ordination of emotional and cognitive limbs of the stress response. J Neuroendocrinol 10:743-757.

Van Bockstaele EJ, Peoples J, Valentino RJ (1999) A.E. Bennett Research Award. Anatomic basis for differential regulation of the rostrolateral perilocus coeruleus region by limbic afferents. Biol Psychiatry 46:1352-1363. Van Bockstaele EJ, Bajic D, Proudfit H, Valentino RJ (2001) Topographic 
architecture of stress-related pathways targeting the noradrenergic locus coeruleus. Physiol Behav 73:273-283.

Vazquez DM, Bailey C, Dent GW, Okimoto DK, Steffek A, López JF, Levine S (2006) Brain corticotropin-releasing hormone (CRH) circuits in the developing rat: effect of maternal deprivation. Brain Res 1121:83-94.

Wallace KJ, Rosen JB (2001) Neurotoxic lesions of the lateral nucleus of the amygdala decrease conditioned fear but not unconditioned fear of a predator odor: comparison with electrolytic lesions. J Neurosci 21:3619-3627.

Wiedenmayer CP, Barr GA (2001) Developmental changes in c-fos expression to an age-specific social stressor in infant rats. Behav Brain Res 126: 147-157.

Wilson DA, Sullivan RM (1991) Olfactory associative conditioning in infant rats with brain stimulation as reward. II. Norepinephrine mediates a specific component of the bulb response to reward. Behav Neurosci 105 843-849.

Winzer-Serhan UH, Broide RS, Chen Y, Leslie FM (1999) Highly sensitive radioactive in situ hybridization using full length hydrolyzed riboprobes to detect alpha 2 adrenoceptor subtype mRNAs in adult and developing rat brain. Brain Res Brain Res Protoc 3:229-241.

Yuan Q, Harley CW, Bruce JC, Darby-King A, McLean JH (2000) Isoproterenol increases CREB phosphorylation and olfactory nerveevoked potentials in normal and 5-HT-depleted olfactory bulbs in rat pups only at doses that produce odor preference learning. Learn Mem 7:413-421. 